\title{
Effects of Concentrical Partial (Local) Compression on the Structural Behavior of Concrete Filled Steel Tubular Column
}

\author{
S. Jayaganesh, ${ }^{1}$ J. Raja Murugadoss, ${ }^{2}$ G. Ganesh Prabhu, ${ }^{2}$ and J. Jegan ${ }^{3}$ \\ ${ }^{1}$ Tamil Nadu Police Housing Corporation Ltd., Madurai Division, Tamil Nadu 625014, India \\ ${ }^{2}$ KPR Institute of Engineering and Technology, Coimbatore, Tamil Nadu 641 407, India \\ ${ }^{3}$ University College of Engineering, Anna University, Ramanathapuram, Tamil Nadu 623513, India \\ Correspondence should be addressed to J. Jegan; drjeganjoe@gmail.com
}

Received 16 June 2015; Revised 7 October 2015; Accepted 20 October 2015

Academic Editor: Stefano Sorace

Copyright (C) 2015 S. Jayaganesh et al. This is an open access article distributed under the Creative Commons Attribution License, which permits unrestricted use, distribution, and reproduction in any medium, provided the original work is properly cited.

\begin{abstract}
The objective of this present paper is to investigate the structural behavior of square and circular Concrete Filled Steel Tubular (CFST) stub columns subjected to axial partial/local compression. The experimental parameters were local compression area and section type. Among the twelve specimens, six specimens were tested under full compression and the remaining six specimens were tested under local compression. The experimental observation indicated that the failure pattern of the CFST column with partial compression is fairly different from the CFST column subjected to full compression. The confinement provided by the circular section is quite different than the confinement provided by the square section, when the CFST column is subjected to axially local compression. It was found that the elastic modulus (stiffness) and the ultimate bearing capacity of the CFST column decreased with the increase in local compression ratio. The circular and square CFST columns subjected to partial/local compression achieved an ultimate strength of $4.45 \%$ and $14.15 \%$, respectively, less than that of the columns subjected to full compression. From the above observation, it can be inferred that the structural performance of the CFST column is significantly influenced by the local area compression ratio and this effect should be taken into account in design models.
\end{abstract}

\section{Introduction}

Over the past several decades, the utilization of Concrete Filled Steel Tubular (CFST) members is being increased in the construction industry $[1,2]$, due to their excellent static and dynamic properties, over equivalent steel and reinforced concrete members. In general, CFST columns are subjected to partial/local compression in several applications, including bearings over piers of girder bridge, and the bottom bearing members of rigid frame or reticulate frame as shown in Figure $1[3,4]$. In the past few decades, boundless researches have been reported on the behavior of CFST column subjected to full compression. Schneider [5] performed an experimental and analytical study on the short CFST column under axial compression and found that the circular tubes have a higher postyield strength and stiffness than those of the square and rectangular section. Kilpatrick and Rangan [6] studied the behavior of slender and stub column filled with high strength concrete. Mursi and Uy [7] investigated the coupled local and global buckling of the CFST column with three different cross-sectional slenderness ratios. In similar manner Sakino et al. [8] investigated the local buckling of the slender CFST column and derived a capacity reduction factor for square section. Liu and Gho [9] found that the EC4 is unsafe to predict the ultimate capacity of CFST columns fabricated using mild steel and high strength concrete. The test results of De Nardin and El Debs [10] showed that the ductility of the CFST column can be increased by using high strength concrete.

In the case of CFST column subjected to full compression, the concrete core and the outer steel tube loaded simultaneously; as a result the confining pressure provided by the steel tube becomes ineffective [11]. Nevertheless, for a CFST column subjected to partial compression, a very small amount of applied load is transferred to the steel tube; as a result the confining pressure provided by the steel tube maximized [12]. It can be inferred that the behavior of the columns subjected 


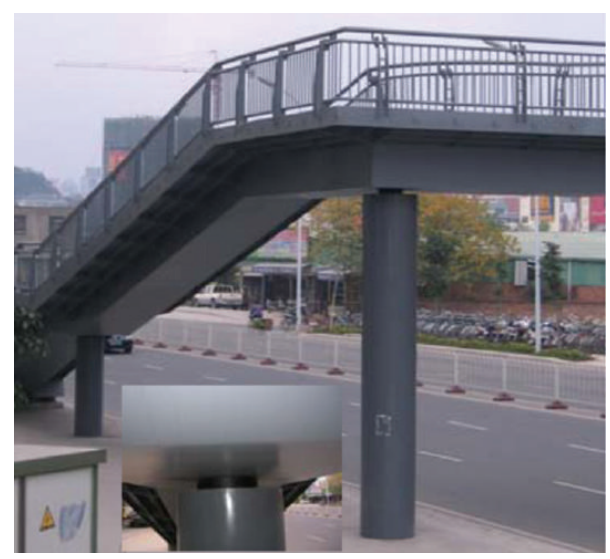

FIGURE 1: CFST column subjected to partial compression [4].

to partial compression is different from those columns subjected to full compression. So, more research effort should be needed on this topic. In recent years, some research has been reported in the CFST column subjected to local compression. Based on the test results of 36 CFST under local compression, Han et al. [11, 12] recognized that the ultimate strength capacity of the locally loaded CFST columns decreases with the increase in local compression area ratio. Yang and Han [3] found that the ductility capacity of the CFST column increases, while being loaded with partial cross-sectional area. Yu et al. [13] analyzed the interaction between the steel tube and its concrete core using the FEA model. From the observation of studies carried out so far, it can be understood that only few researches have been focused on the behavior of CFST column subjected to local compression. Furthermore, there is still a lack of information on the CFST column subjected to local compression. Accordingly, studies are needed to address the further research in this area. With this aim, the main objective of this experimental investigation is to examine the behavior of CFST column subjected to partial compression. The experimental parameters were local area compression area $(\beta)$ and cross-sectional type (square and circular). All the columns were tested to failure and the influence of the experimental parameters on the behavior of CFST column was analyzed. The ultimate strength capacity of the CFST column subjected to partial compression was evaluated using a simplified equation.

\section{Experimental Studies}

2.1. Materials. Commercially available hollow square and circular section conforming to IS 4923 [14] and IS 1161 [14], respectively, and having a size and diameter of $100 \times$ $100 \mathrm{~mm}$ and $101.6 \mathrm{~mm}$, respectively, was used in this study. The thickness of the hollow square and circular steel tube was about $4 \mathrm{~mm}$. The height of the column was $300 \mathrm{~mm}$, which is three times the cross-sectional dimension. Three coupons were machined from the square and circular steel tube and tested for tension. The measured average yield strength of the steel tube was $358 \mathrm{~N} / \mathrm{mm}^{2}$ and Poisson's ratio $(\mu)$ was about 0.281 . The infilled concrete was designed to achieve a compressive strength of $60 \mathrm{~N} / \mathrm{mm}^{2}$. The designed water cement ratio was 0.35. Ordinary Portland Cement (OPC) was used to prepare infilled concrete. Natural river sand passing through a $4.75 \mathrm{~mm}$ sieve and coarse aggregate with a nominal size of $10 \mathrm{~mm}$ was used to prepare this mixture [15]. To improve the workability of the concrete, super plasticizer belonging to modified melamine formaldehyde chemical family was used. A test was performed to determine the 28 day compressive strength using $150 \mathrm{~mm} \times 150 \mathrm{~mm} \times 150 \mathrm{~mm}$ cubes. The average strength of the concrete obtained was about $61.55 \mathrm{~N} / \mathrm{mm}^{2}$.

2.2. Specimen Fabrication. Circular and square hollow tubes $300 \mathrm{~mm}$ in height were machined from $6 \mathrm{~m}$ long hollow tubes. To obtain a level surface, both ends of the steel tube were levelled using a lathe. Before filling the tube with concrete, the inside portion was thoroughly wire brushed to remove rust and loose debris presented. For concrete mixtures, aggregates were weighed in dry condition and the mixtures were mixed together for 5 to $10 \mathrm{~min}$ in a countercurrent mixer. Then the steel tube was then filled with concrete, layer by layer, and each layer was effectively compacted by the vibrator to ensure the concrete was free from air gaps and flaws. During compaction, a steel plate was introduced at the bottom of the steel tube to eliminate the leakage of slurry, and then the concrete was allowed to cure for 28 days.

\subsection{Experimental Setup. All the CFST columns were tested in} a compression testing machine having a capacity of $2000 \mathrm{kN}$ and the specimens were tested under axial compression. Each member was placed on the supports, and care was taken to ensure that its centerline was exactly in line with the axis of the machine [16]. On all the columns, instruments were installed to measure the axial and lateral deformation using linear voltage displacement transducers (LVDTs), and $2000 \mathrm{kN}$ load cell was used to monitor the load. Both load cell and LVDTs were connected to the 16-channel data acquisition system to store the data. The load was applied to the columns using a jack and they were tested to failure. A circular bearing plate was used to achieve the local compression. All the specimens were tested to failure and the loading rate was maintained as $1 \mathrm{~mm} / \mathrm{min}$ displacement. The experimental observation recorded the nature of the failure, axial deformation, and ultimate load. The loading setup of CFST specimen subjected to full and partial compression is shown in Figure 2.

2.4. Specimen Designation. The objective of this investigation is not limited to evaluating the strength capacity of the CFST column under local compression, also to understand the failure modes and ductility response of the CFST column under local compression. Two types of sections including circular and square sections were investigated. Among the twelve specimens tested under axial compression, six specimens (three circular and three square sections) were tested under full compression and the remaining six specimens (three circular and three square sections) were tested under local compression. The partial compression specimens with 


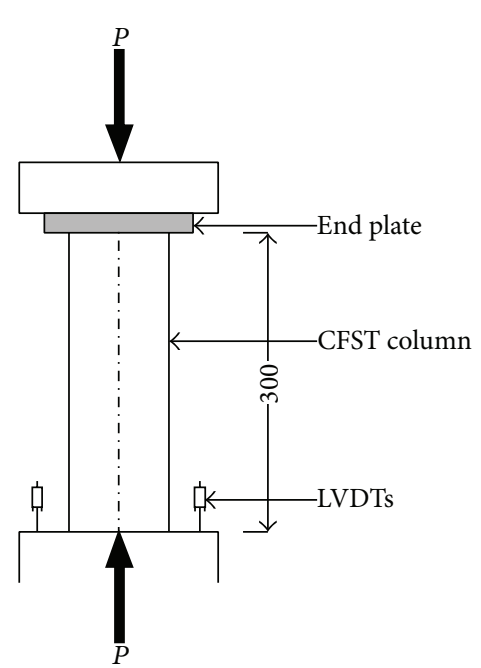

(a)

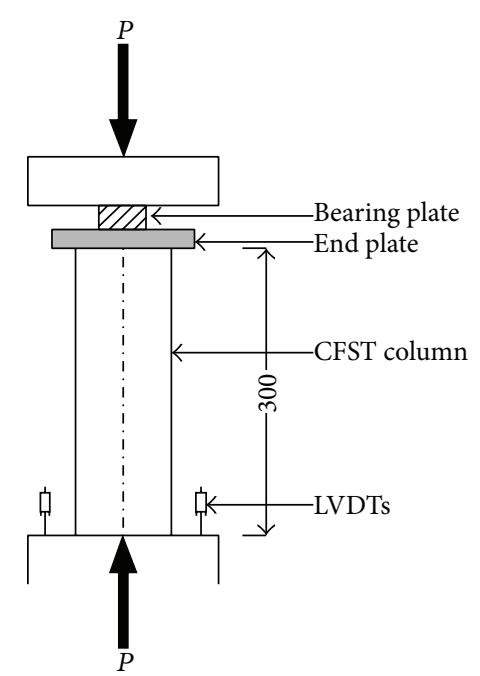

(b)

FIGURE 2: Full and partial compression testing setup.

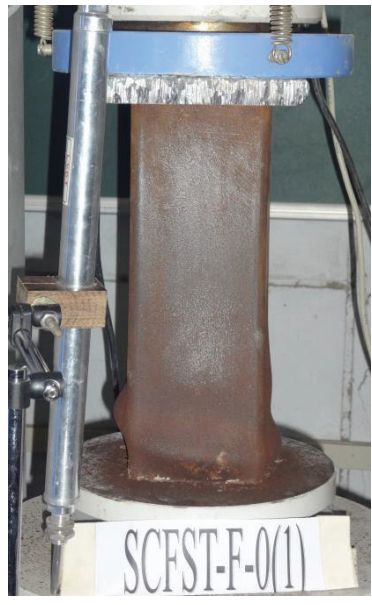

SCFST-F-0(1)

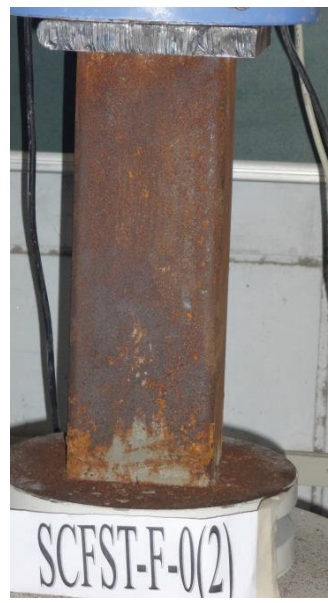

SCFST-F-0(2)

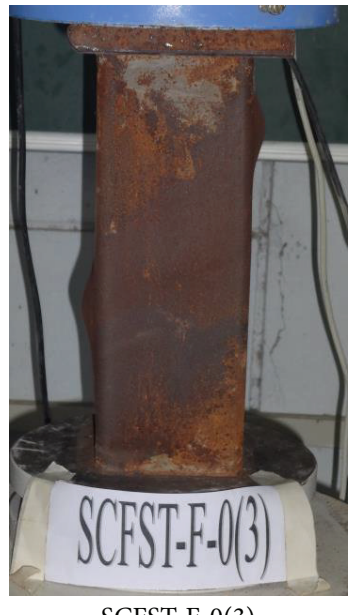

SCFST-F-0(3)

FIGURE 3: Failure pattern of square CFST column subjected to full compression.

the local compression area ratio of 2 were continued $(\beta=$ $A_{\text {CFST }} / A_{\text {LC }} ; A_{\text {CFST }}$ is the cross-sectional area of the CFST column; $A_{\mathrm{LC}}$ is the area of local compression $\left(4415 \mathrm{~mm}^{2}\right)$ ) and Figure 2 shows the schematic view of the CFST section under full and partial compression. The steel plate with the thickness of $7 \mathrm{~mm}$ was used to apply the load to the column. The summary of the specimen details is presented in Table 1. To identify the specimen easily, the columns were designated using names such as CCFST-F-1, CCFST-F-2, CCFST-F-3, CCFST-P-1, CCFST-P-2, CCFST-P-3, SCFST-F-1, SCFST-F2, SCFST-F-3, SCFST-P-1, SCFST-P-2, and SCFST-P-3. For example, the name of specimens CCFST-F-2 and CCFST-P3 specifies that the circular CFST column is subjected to full and partial compression, respectively. The numeral refers to the number of specimens.

\section{Results and Discussions}

3.1. Failure Modes. The CFST columns tested under full and partial compression exhibited a ductile behavior, and the decrease in the compression loading area significantly influences the behavior of CFST column. In the case of square CFST columns under full compression, exhibited an outward buckling of steel tube observed at the bottom and mid height of the column as shown in Figure 3. There was no cracking of concrete observed on the top surface of the CFST column. Due to the full compression, the steel tube in the outer limits directly carried the applied load and also provides confinement to the inner concrete core. This composite action avoids the cracking of inner core concrete and led to the buckling of steel tube. In the case of square CFST columns 


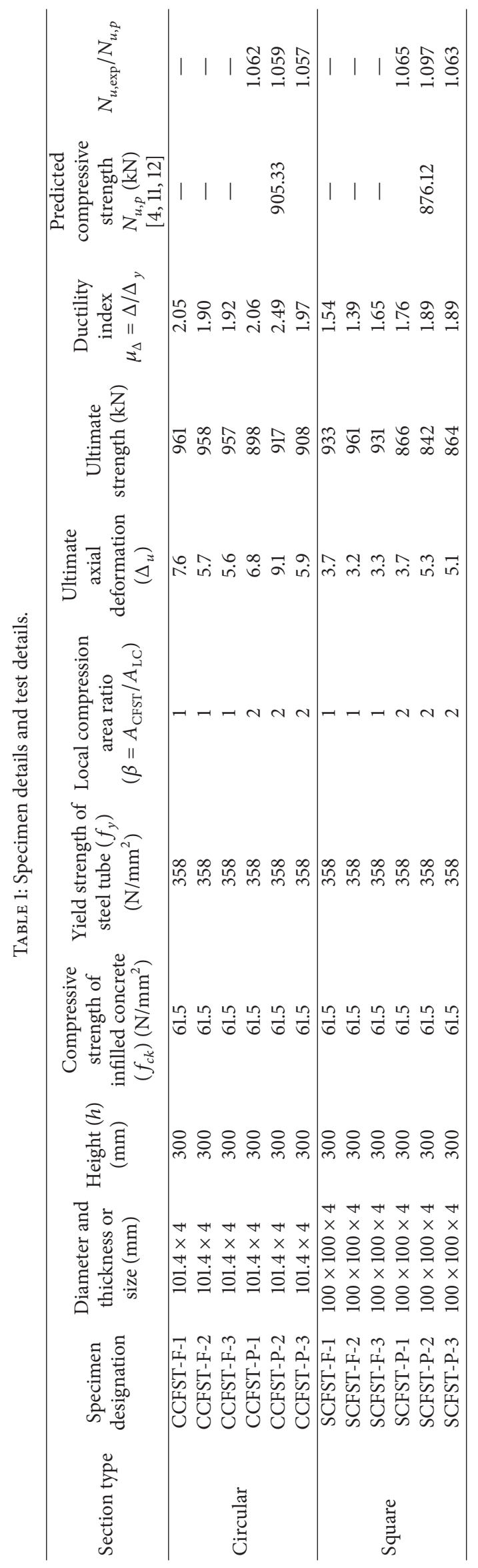




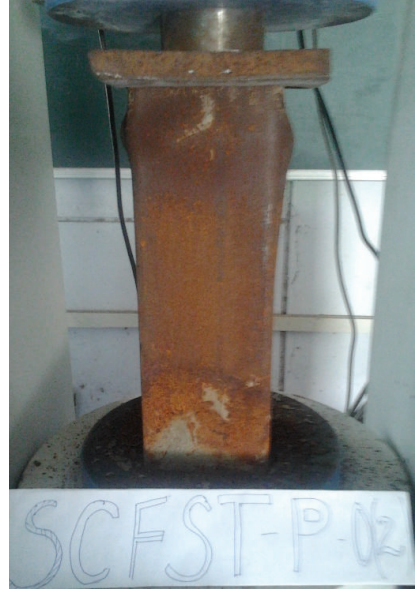

SCFST-P-0(2)

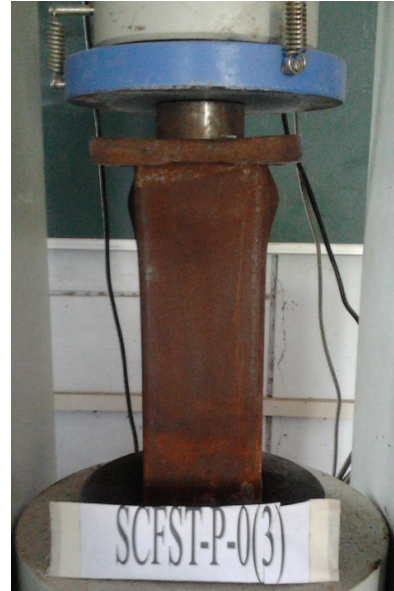

SCFST-P-0(3)
FIGURE 4: Failure pattern of square CFST column subjected to partial/local compression.

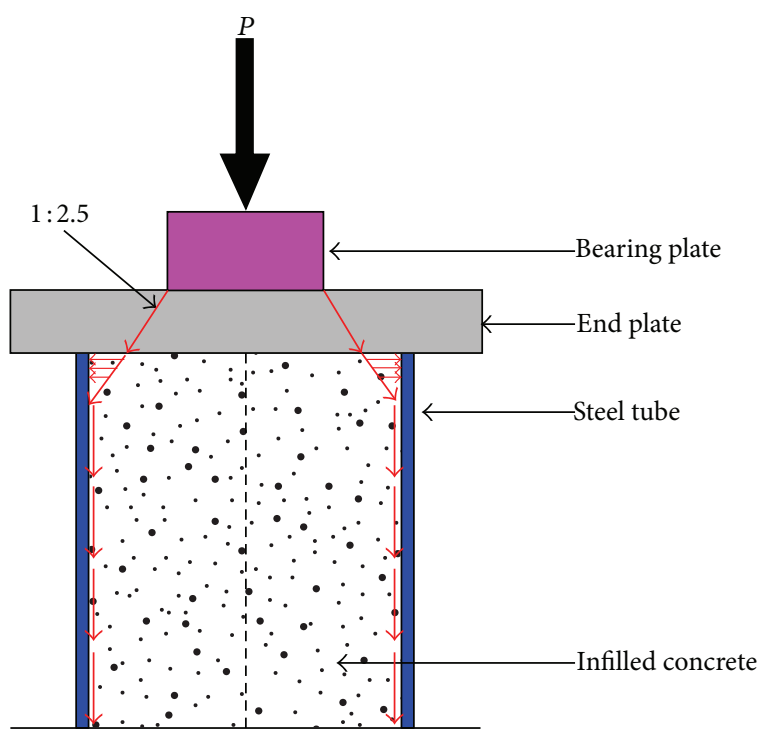

FIGURE 5: Load transferring mechanism of partial and full compression [4].

under partial compression, the concrete immediately below the loading area cracked noticeably due to the punching effect of load and buckling of steel tube occurred at the top of the column which is shown in Figure 4. The load transferring mechanism of the CFST columns under partial compression is shown in Figure 5. When the partial load is applied, the concrete in the top layer started to crack due to the punching effect of applied load and creates an increase in volume of concrete, and this led to the faster increase on the lateral strain in steel tube. As a result the buckling of steel tube occurred very near to the loading area. It was observed that the cracking of concrete was initiated beneath the loading point and spread towards the four corners of the steel tube. From this it can be inferred that, in square CFST columns, the confinement to the concrete core mainly comes from the corner and a small part of the concrete only effectively confined by the steel tube $[11,12]$.

The circular CFST column tested under full compression failed through outward buckling of steel tube observed at the center of the column as shown in Figure 6. Furthermore, no obvious cracking was observed in top concrete. In the case of a circular column tested under partial compression, once cracking of concrete initiated beneath the loading area, the steel tube in the outer limits provided more confinement to the concrete core; loading further, the concrete cracks were spread uniformly around the steel tube providing more confinement to the concrete core. Finally, the columns failed through outward buckling of steel tube observed at mid height of the column as shown in Figure 6. The load transferring mechanism to the mid height of the circular column is shown in Figure 5. With reference to the crack pattern of the concrete core, it can be inferred that the confinement provided by the circular steel tube is uniform, and the whole part of the concrete effectively is confined by the steel tube [11]. Furthermore, it can be inferred that the confinement provided by the circular section is quite different than the confinement provided by the square section. In the case of column tested under partial compression in both square and circular sections, a sudden drop-off in loading was observed at the failure load; particularly this observation was very obvious in square section under partial compression. This sudden drop-off in the loading is attributed to the crushing failure of concrete.

3.2. Axial Stress-Strain Behavior and Ductility. The experimental results with regard to ultimate axial deformation of the columns are listed in Table 1 . The ultimate axial deformation $\left(\Delta_{u}\right)$ of the column obtained is the axial deformation of the column, when the load falls to $80 \%$ of its ultimate load. The axial applied stress-strain behavior of all the columns is shown in Figures 7 and 8. From Figures 7 and 8, it can be understood that the elastic modulus of the column with partial compression is lower than the column with full compression in both square and circular columns. Moreover, the immediate fall in the curve was observed at the ultimate stage in column with partial compression due to the crushing failure of concrete. In the case of circular columns, the axial stress-strain behavior of the column with partial compression was relatively similar to the column with full compression. However, the column with full compression achieved higher ultimate strength when compared to the column with partial compression. At the respective failure load of a circular column with partial compression (CCFST-P-3), the deformation of the circular column with full compression (CCFST-F-3) was about $3.9 \mathrm{~mm}$, which is $63.88 \%$ lesser than the column with partial compression. As said earlier, the decrease in the stiffness of the column with partial compression may be due to the punching effect of the partial compression. Due to this punching effect, the concrete core beneath the compression area started to crack and creates an increase in volume of concrete, and this led to the faster increase on the lateral strain in steel tube. As a result the buckling of steel tube occurred very near to the loading area. The above similar trend was observed in the case of square columns under partial 


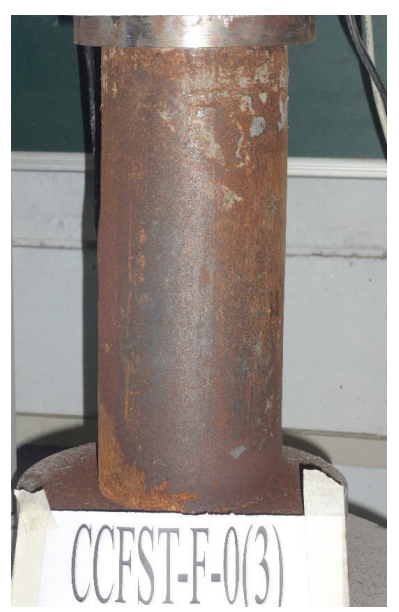

CCFST-F-0(3)

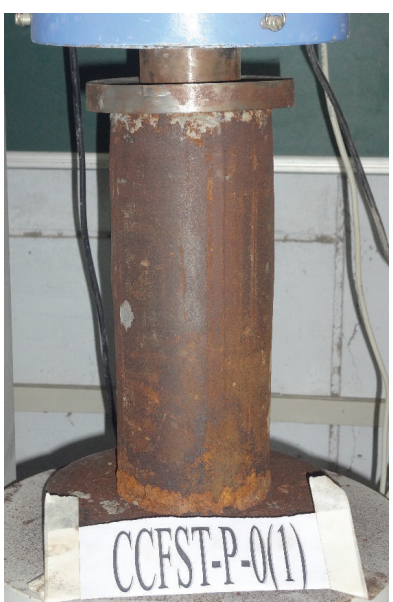

CCFST-P-0(1)

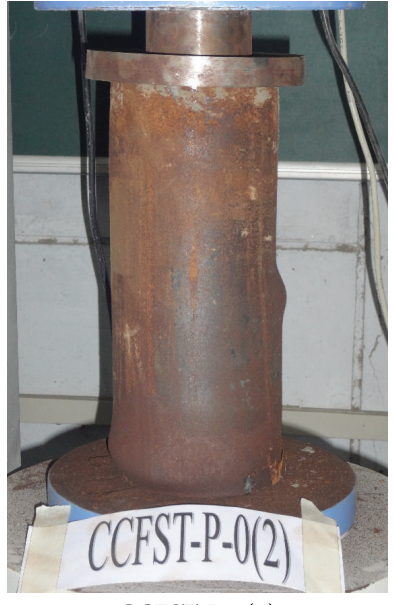

CCFST-P-0(2)

FIGURE 6: Failure pattern of circular CFST column subjected to full and partial compression.

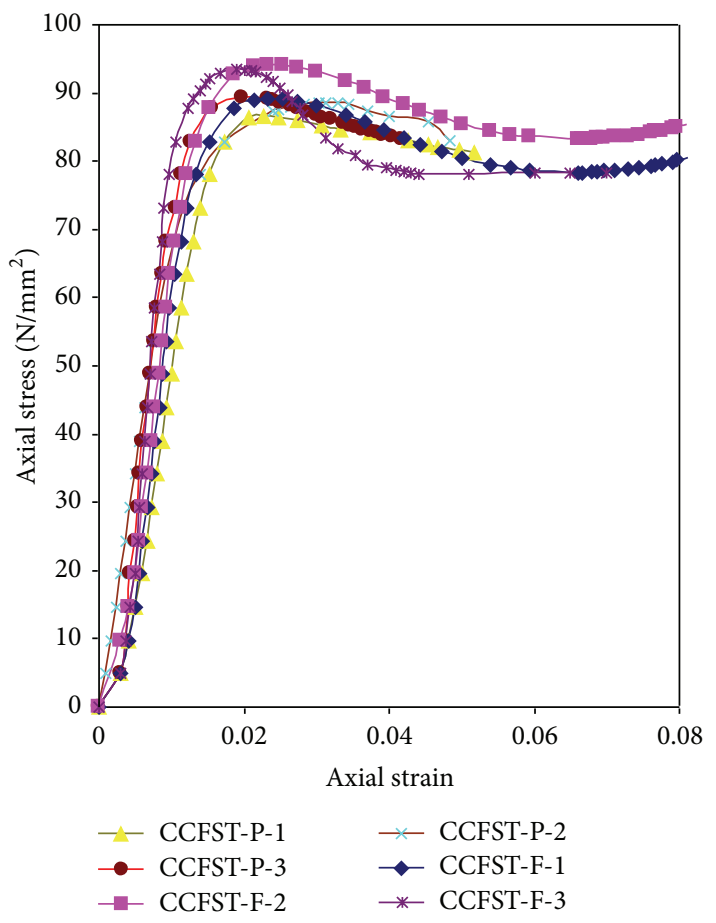

FIGURE 7: Axial stress-strain behavior of circular CFST column subjected to full and partial compression-comparison.

compression; furthermore the immediate fall in the curve at the ultimate state was very abrupt when compared to the circular column. The column with full compression (SCFSTF-2) achieved a deformation of $2.8 \mathrm{~mm}$ at the respective failure load of column with partial compression; in addition, this deformation was $89.28 \%$ lesser than the column with partial compression $(5.3 \mathrm{~mm})$. Han et al. [11, 12] documented that, for square section, the formation of lateral strain at the top corresponding to the ultimate strength is larger than that of the lateral strain in the middle. The obtained experimental results fairly agreed with the finding of Han et al. [11, 12]

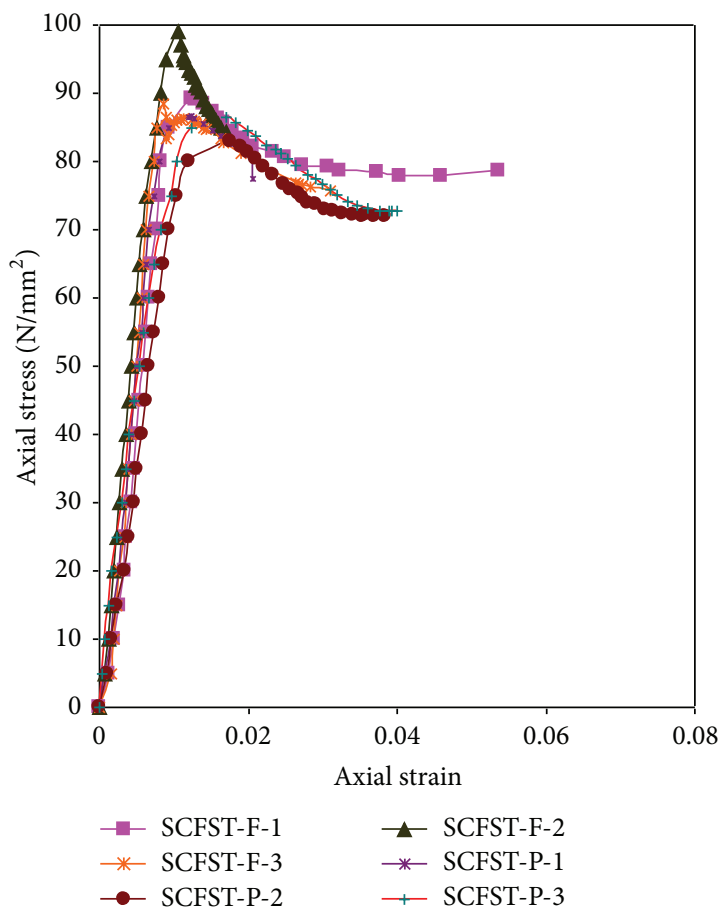

FIGURE 8: Axial stress-strain behavior of square CFST column subjected to full and partial compression-comparison.

and this can be evident from Figure 4. The crack in the concrete beneath the partial compression led to the faster increase in the lateral strain at the top, and this led to the buckling of steel tube, very near to the loading area. From Figure 7, it can be understood that the fall in the curve of the circular specimen at the ultimate load was very smooth due to the even confining pressure provided by the circular steel tube. For square specimen it was abrupt due to the confining pressure provided only from the corners. From the observation, it can be inferred that the confinement action between the concrete and the steel tube for square section 


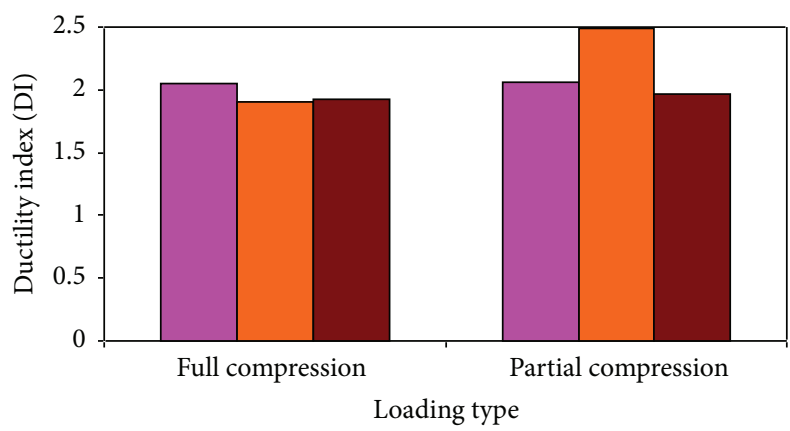

FIGURE 9: Ductility behavior of circular CFST column subjected to full and partial compression-comparison.

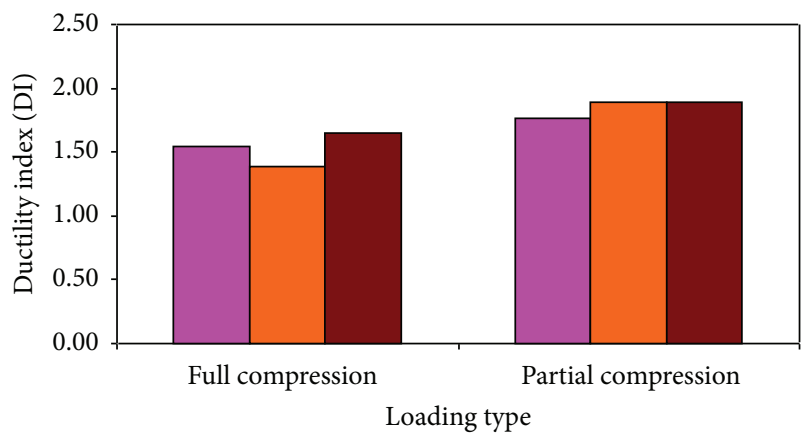

FIGURE 10: Ductility behavior of square CFST column subjected to full and partial compression-comparison.

is not significant, when compared to the composite action between the concrete and the steel tube for circular section.

The displacement ductility index of all the CFST columns was calculated using (1) obtained from the idealized bilinear curve [17] that was ascertained from the load-deformation behavior of the column, where $\mu_{\Delta}$ is the displacement ductility index of the column; $\Delta$ is the axial deformation of the column, when the load falls to $85 \%$ of the ultimate load; $\Delta_{y}$ is the deformation at the respective yield load of the column:

$$
\mu_{\Delta}=\frac{\Delta}{\Delta_{y}} .
$$

From Figures 9 and 10, it can be understood that the column subjected to local compression showed higher ductility when compared to the column subjected to full compression; however, the difference in the ductility index was not significant. The experimental finding of Yang and Han [3] also revealed the same. The increase in the ductility index may be due to the fact that, for columns subjected to partial compression, the steel tube in the outer limit did not bear the load directly and provides effective confinement to the concrete. As a result, the ductility of the column increased somewhat more. For instance, the square column subjected to full compression (SCFST-F-1) exhibited a ductility index of 1.54 , whereas the square column subjected to partial compression achieved a ductility index of 1.74 , which is $10.81 \%$ higher than that of the column subjected to full compression. The above similar trend was observed in the circular

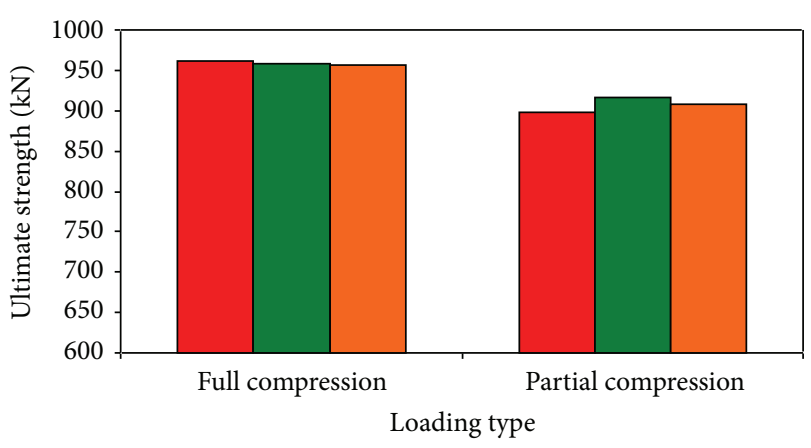

FIGURE 11: Ultimate strength of circular CFST column subjected to full and partial compression-comparison.

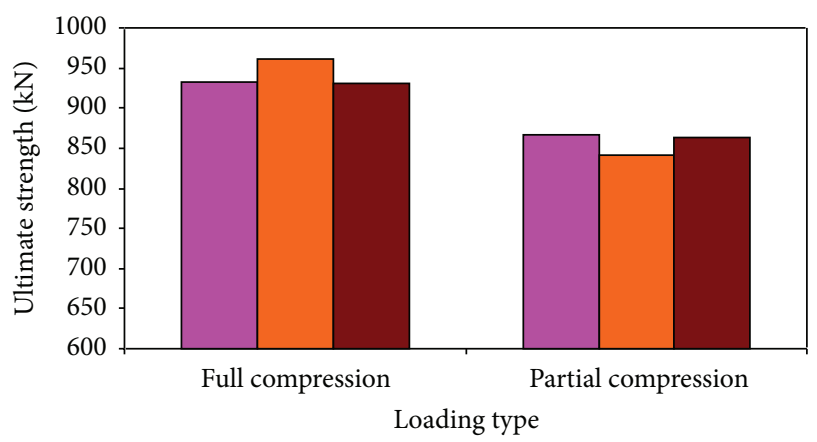

FIGURE 12: Ultimate strength of square CFST column subjected to full and partial compression-comparison.

columns subjected to partial and full compression; however, the ductility behavior of the circular columns was more obvious when compared to the square column.

3.3. Ultimate Strength. The measured ultimate strength of all the CFST columns under partial and full compression is listed in Table 1 and presented in Figures 11 and 12. From Figures 11 and 12, it can be understood that both square and circular CFST columns under partial compression achieved lower strength, whereas the columns under full compression showed higher strength. The column CCFST-P-2 achieved a strength of $917 \mathrm{kN}$, which is $4.45 \%$ lesser than that of the CCFST-F-2. In a similar manner, the square section under full compression (SCFST-F-2) exhibited an ultimate strength of $961 \mathrm{kN}$, whereas the column SCFST-P-2 achieved a strength of $842 \mathrm{kN}$ which is $14.15 \%$ less. The decrease in ultimate strength of the column under partial compression is attributed to the cracking of the core concrete due to the punching load. Moreover, the decrease in ultimate strength of the square section was significant when compared to the circular section. The difference in ultimate strength between the circular sections under full and partial compression was about $51 \mathrm{kN}$, whereas the square section showed a difference of $69 \mathrm{kN}$. From this observation, it can be inferred that the confinement effect provided by the circular steel tube is more effective than that of the square section and the decrease in the compression area significantly affects the strength capacity of the CFST column. 


\section{Theoretical Evaluation of Bearing Capacity}

In the design model of the CIDECT report [18] and EN 19941-1 [19], the influence of local compression on the ultimate strength capacity of CFST columns was considered and the effects of the confinement of the steel tube were addressed. Equation (2) was proposed to evaluate the bearing capacity of the CFST column subjected to partial compression $\left(N_{u, p}\right)$ :

$$
\begin{aligned}
N_{u, p} & =A_{1} f_{c d}^{\prime}\left(1+\eta_{c l} \frac{t}{a} \frac{f_{y}}{f_{c k}^{\prime}}\right) \sqrt{\frac{A_{c}}{A_{1}}} \\
& \leq\left(f_{c d}^{\prime} A_{c}+f_{y d} A_{1}\right),
\end{aligned}
$$

where $A_{1}$ is the local compression area; $f_{c d}^{\prime}$ and $f_{c k}^{\prime}$ are the design and characteristic compressive strength of concrete, respectively; $\eta_{c l}$ is the factor depending upon the confinement of the steel tube (generally 4.9 and 3.5 for circular and square steel tubes, resp.); $a$ and $t$ are the size and thickness of the steel tube; $f_{y d}$ is the design yield strength value of the steel tube. In the above model [18, 19], the load distribution over the thickness of the steel plate was assumed with the ratio of $1: 2.5$ as shown in Figure 6, if the CFST column is subjected to local compression.

Based on the experimental results obtained, Han et al. $[2,3,12]$ proposed (3) to predict the bearing capacity of the CFST column subjected to partial compression. In this model the bearing capacity of the local compression CFST column was determined from the CFST column subjected to full compression by applying strength index factor:

$$
N_{u, p}=k_{p} \cdot N_{u}
$$

where $N_{u}$ is the bearing capacity of the CFST column subjected to full compression and $k_{p}$ is the strength index factor and can be evaluated through the following equations taking into account the section type.

For circular section $[2,3,12]$,

$$
\begin{aligned}
k_{p}= & \left(A_{0} \cdot \beta+B_{0} \cdot \beta^{0.5}+C_{0}\right) \\
& \cdot\left(D_{0} \cdot n_{r}^{2}+E_{0} \cdot n_{r}+1\right),
\end{aligned}
$$

where $A_{0}=\left(-0.17 \xi^{3}+1.9 \xi^{2}-6.84 \xi+7\right) / 100 ; B_{0}=\left(1.35 \xi^{3}+\right.$ $\left.14 \xi^{2}+46 \xi-60.8\right) / 100 ; C_{0}=\left(-1.08 \xi^{3}+10.95 \xi^{2}-35.1 \xi+\right.$ $150.9) / 100 ; D_{0}=\left(-0.53 \beta-54 \beta^{0.5}+46\right) / 100 ; E_{0}=(6 \beta+$ $\left.62 \beta^{0.5}-67\right) / 100$. $\xi$ and $n_{r}$ are the confinement factor and relative rigidity radius of the end plate, respectively, which are determined using (5) and (6) [2, 4, 12]:

$$
\begin{aligned}
\xi & =\frac{A_{s}}{A_{c}} \cdot \frac{f_{y}}{f_{c k}^{\prime}} \\
n_{r} & =\left(\frac{16}{12\left(1-\mu_{s}^{2}\right)}\right)^{0.25} \cdot\left(\frac{E_{s} t_{a}^{3} a}{\bar{E} a^{4}}\right)^{0.25},
\end{aligned}
$$

where $A_{s}$ and $A_{c}$ are the cross-sectional area of the steel and concrete, respectively, and $\bar{E}\left(\left[E_{s} \cdot A_{s}+E_{c} \cdot A_{c}\right] / A_{s c}\right)$ is the elastic modulus of the composite CFST column.

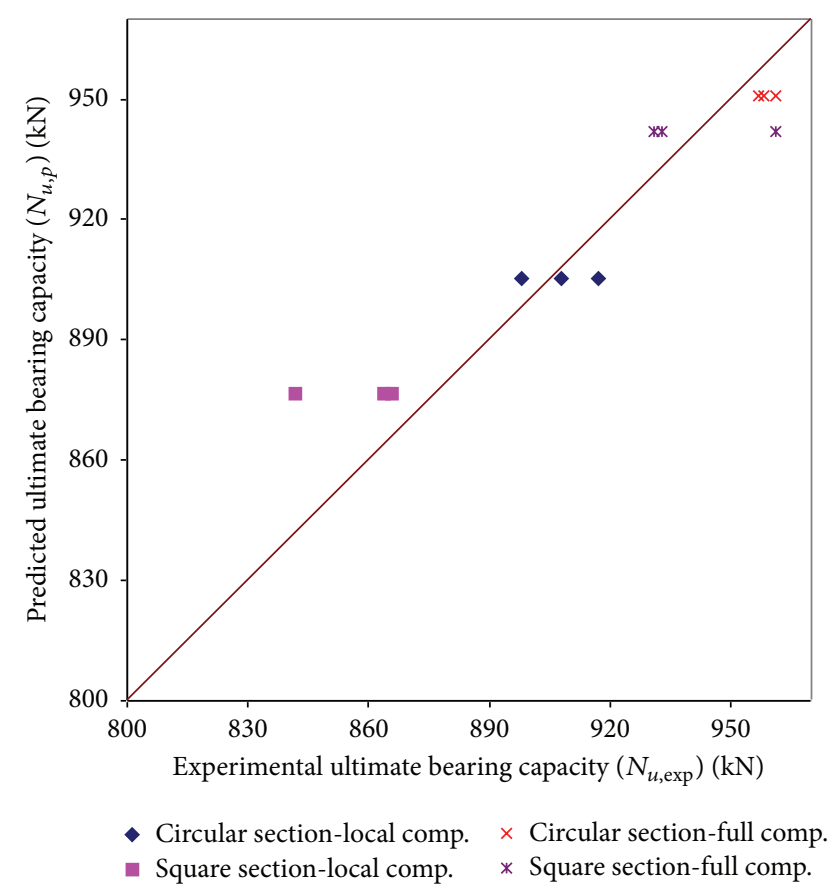

FIGURE 13: Correlation between predicted and experimental ultimate strength of square and circular CFST column subjected to partial compression.

For square section $[2,12]$,

$$
k_{p}=\left(A_{0} \cdot \beta^{-1}+B_{0} \cdot \beta^{-0.5}+C_{0}\right) \cdot\left(D_{0} \cdot n_{r}+1\right),
$$

where $A_{0}=(35.45 \xi+26.9) / 100 ; B_{0}=(-40.62 \xi+74.50 .8) /$ $100 ; C_{0}=(5.2 \xi-0.93) / 100 ; D_{0}=\left(103.2 \beta^{0.5}-53.11\right) / 100$. The ultimate bearing capacity of the CFST column subjected to local compression of the present study was evaluated using the above proposed models $[4,11,12]$ and the predicted values are summarized in Table 1. Figure 13 shows the correlation made between the tested and predicted bearing capacity of the CFST column subjected to local compression. From Figure 13, it can be understood that the models proposed by Han et al. $[4,11,12]$ are conservative to predict the bearing capacity of the CFST column subjected to local compression; furthermore, the model provided the closest prediction.

\section{Conclusion}

An experimental investigation was performed to understand the structural behavior of CFST stub columns subjected to partial/local compression. Based on the test results of twelve specimens, the following conclusions were made:

(i) The failure pattern of the CFST column subjected to partial compression was obviously different than that of the CFST column subjected to full compression.

(ii) While being the CFST column subjected to partial compression, the confinement provided by the circular section is quite different than the confinement provided by the square section; furthermore the confinement action between the concrete and the steel 
tube for circular section was significant compared to that of the square section.

(iii) The columns subjected to local compression achieved the low stiffness and bearing capacity, when compared to the column subjected to full compression. The circular column with partial compression decreased its stiffness and ultimate strength by $63.88 \%$ and $4.45 \%$, respectively, when compared to the column with full compression.

(iv) The higher confinement provided by the steel tube in partial compression increased the ductility performance of the CFST column; furthermore it was very obvious in circular section.

(v) A theoretical bearing capacity of the CFST columns subjected to partial compression was predicted using simple equations and the predicted values were in good agreement with the experimental results.

\section{Conflict of Interests}

The authors declare that there is no conflict of interests regarding the publication of this paper.

\section{References}

[1] G. Muciaccia, F. Giussani, G. Rosati, and F. Mola, "Response of self-compacting concrete filled tubes under eccentric compression," Journal of Constructional Steel Research, vol. 67, no. 5, pp. 904-916, 2011.

[2] G. G. Prabhu and M. C. Sundarraja, "Behaviour of concrete filled steel tubular (CFST) short columns externally reinforced using CFRP strips composite," Construction and Building Materials, vol. 47, pp. 1362-1371, 2013.

[3] Y.-F. Yang and L.-H. Han, "Experiments on rectangular concrete-filled steel tubes loaded axially on a partially stressed cross-sectional area," Journal of Constructional Steel Research, vol. 65, no. 8-9, pp. 1617-1630, 2009.

[4] Y. F. Yang and L. H. Han, "Concrete filled steel tube (CFST) columns subjected to concentrically partial compression," ThinWalled Structures, vol. 50, no. 1, pp. 147-156, 2012.

[5] S. P. Schneider, "Axially loaded concrete-filled steel tubes," Journal of Structural Engineering, vol. 124, no. 10, pp. 1125-1138, 1998.

[6] A. E. Kilpatrick and B. V. Rangan, "Tests on high-strength concrete-filled steel tubular columns," ACI Structural Journal, vol. 96, no. 2, pp. 268-274, 1999.

[7] M. Mursi and B. Uy, "Strength of concrete filled steel box columns incorporating interaction buckling," Journal of Structural Engineering, vol. 129, no. 5, pp. 626-639, 2003.

[8] K. Sakino, H. Nakahara, S. Morino, and I. Nishiyama, "Behavior of centrally loaded concrete-filled steel-tube short columns," Journal of Structural Engineering, vol. 130, no. 2, pp. 180-188, 2004.

[9] D. Liu and W.-M. Gho, "Axial load behaviour of high-strength rectangular concrete-filled steel tubular stub columns," ThinWalled Structures, vol. 43, no. 8, pp. 1131-1142, 2005.

[10] S. De Nardin and A. L. H. C. El Debs, "Axial load behaviour of concrete-filled steel tubular columns," Proceedings of the
Institution of Civil Engineers: Structures and Buildings, vol. 160, no. 1, pp. 13-22, 2007.

[11] L.-H. Han, W. Liu, and Y.-F. Yang, "Behavior of thin walled steel tube confined concrete stub columns subjected to axial local compression," Thin-Walled Structures, vol. 46, no. 2, pp. 155-164, 2008.

[12] L.-H. Han, W. Liu, and Y.-F. Yang, "Behaviour of concretefilled steel tubular stub columns subjected to axially local compression," Journal of Constructional Steel Research, vol. 64, no. 4, pp. 377-387, 2008.

[13] Q. Yu, Z. Tao, W. Liu, and Z.-B. Chen, "Analysis and calculations of steel tube confined concrete (STCC) stub columns," Journal of Constructional Steel Research, vol. 66, no. 1, pp. 53-64, 2010.

[14] IS 4923:1997: Indian standard Hollow steel sections for structural use-Specification, Second revision.

[15] Bureau of Indian Standards, IS 2720(Part 3): Methods of Test for Aggregates for-Specification, Bureau of Indian Standards, New Delhi, India, 1980.

[16] M. C. Sundarraja, P. Sriram, and G. Ganesh Prabhu, "Strengthening of hollow square sections under compression using FRP composites," Advances in Materials Science and Engineering, vol. 2014, Article ID 396597, 19 pages, 2014.

[17] M. C. Sundarraja and G. G. Prabhu, "Experimental study on CFST members strengthened by CFRP composites under compression," Journal of Constructional Steel Research, vol. 72, pp. 75-83, 2012.

[18] R. Bergman, C. Matsui, C. Meinsma, and D. Dutta, CIDECT Design Guide for Concrete-Filled Hollow Section Columns under Static and Seismic Loading, TÜV Rheinland, 1995.

[19] EN, "Eurocode 4: design of composite steel and concrete structures, part 1-1: general rules and rules for buildings," EN 1994-1-1, British Standards Institution, European Committee for Standardisation, London, UK, 2004. 

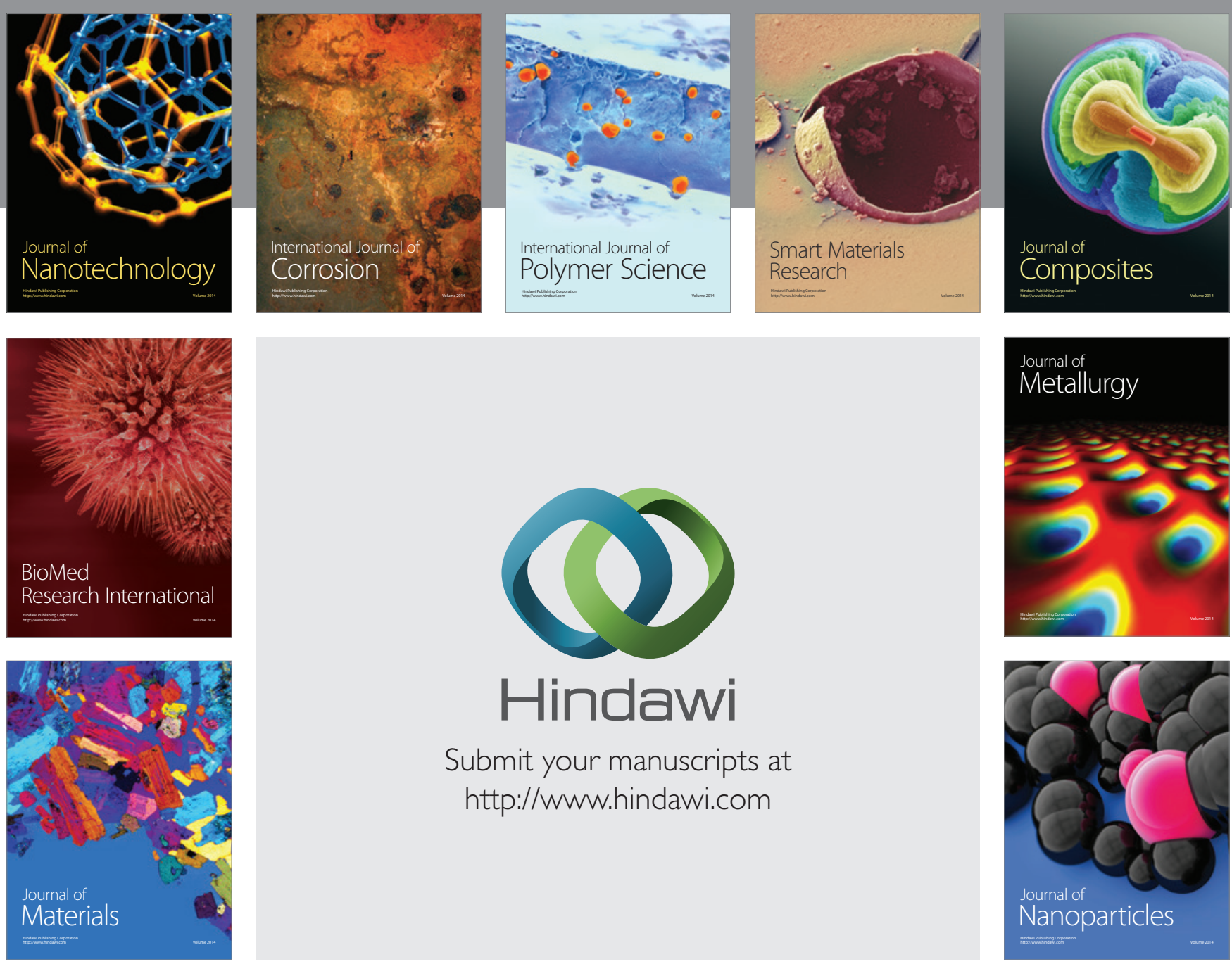

Submit your manuscripts at http://www.hindawi.com
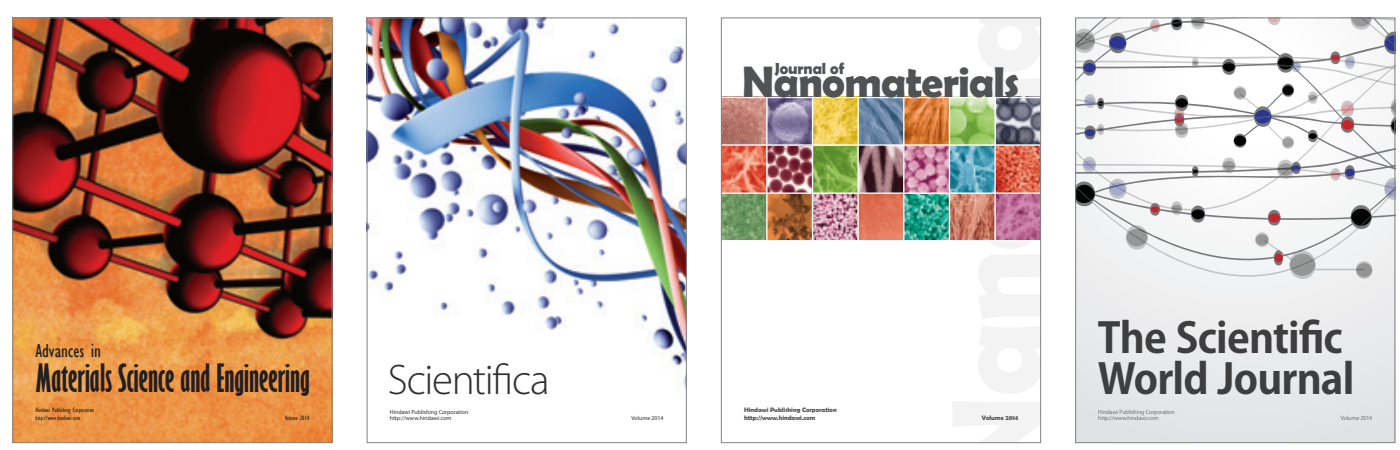

\section{The Scientific World Journal}
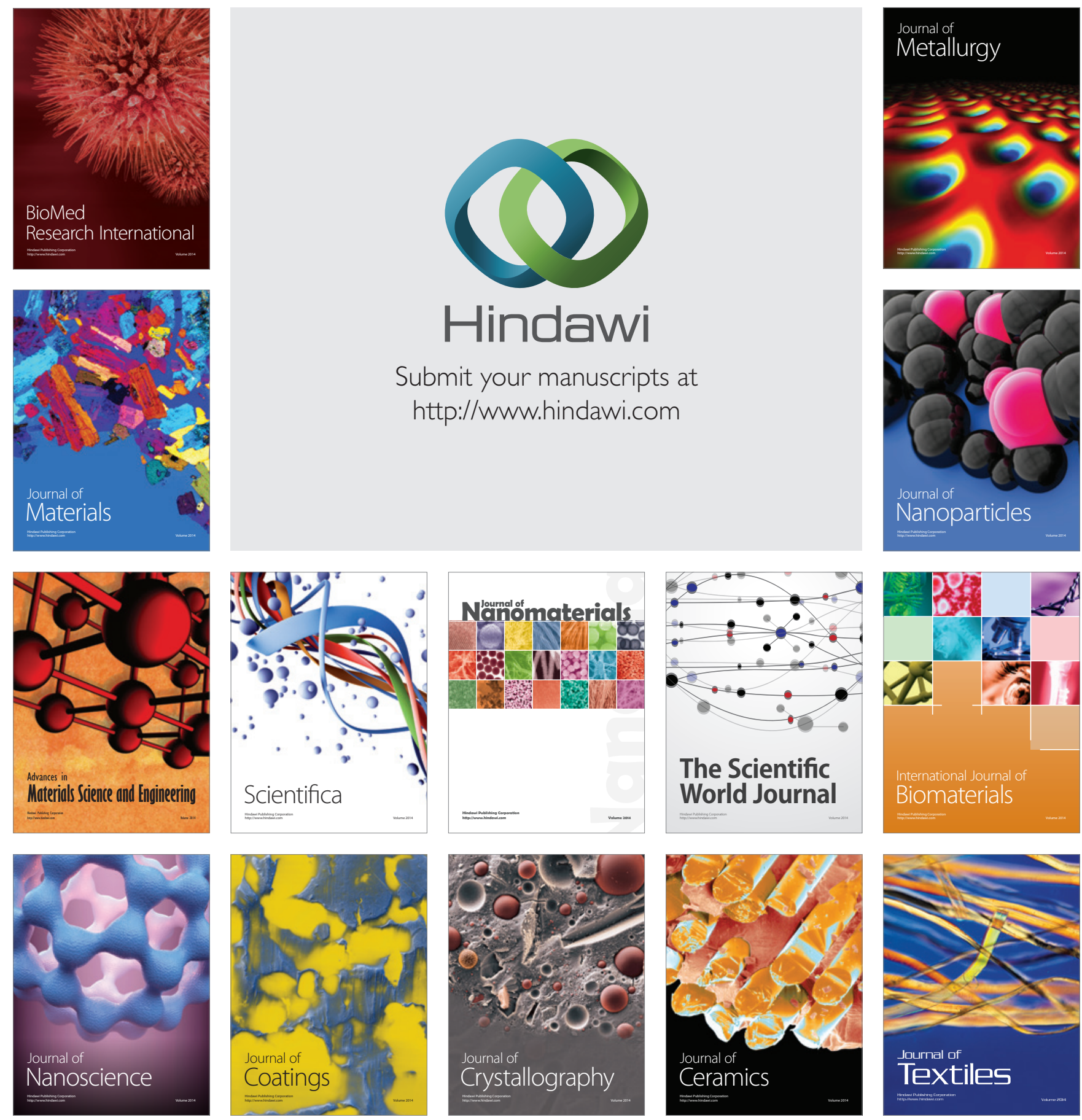